\title{
Analisis Pemasaran Buncis di Desa Oerinbesi Kecamatan Biboki Tanpah Kabupaten Timor Tengah Utara
}

\author{
Yohana Albertin Pay ${ }^{\mathrm{a}}$, dan Agustinus Nubatonis ${ }^{\mathrm{b}}$ \\ ${ }^{a}$ Fakultas Pertanian, Universitas Timor, Kefamenanu, TTU - NTT, Indonesia. \\ ${ }^{b}$ Fakultas Pertanian, Universitas Timor, Kefamenanu, TTU - NTT, Indonesia.
}

\section{Article Info}

Article history:

Received 11 Juni 2017

Received in revised form 20 Juli 2017

Accepted 4 Oktober 2017

\section{Keywords:}

Pemasaran

Buncis

Oerinbesi

Biboki Tanpah

\section{Abstrak}

Buncis merupakan sayuran yang berpotensi ekonomi tinggi karena mempunyai peluang pasar yang cukup luas. Penelitian dan publikas tentang pemasaran komoditi pertanian, dan perikanan di wilayah kabupaten TTU masih sangat minim, hal ini menyebabkan berbagai pihak terkait sulit untuk mendapatkan informasi yang bisa digunakan sebagai pijakan pengambilan keputusan oleh pemerintah, produsen, pedagang maupun konsumen yang lebih berpihak kepada petani produsen. Penelitian ini bertujuan untuk mengetahui 1) saluran pemasaran; 2) margin pemasaran; 3) farmer share; dan 4) efisiensi pemasaran buncis di desa Oerinbesi, kecamatan Biboki Tanpah, kabupaten TTU. Penelitian ini dilaksanakan di desa Oerinbesi, kecamatan Biboki Tanpah, kabupaten TTU pada bulan Februari sampai Juli 2017 dengan petani sampel sebanyak 35 petani buncis. Metode analisis yang digunakan adalah deskriptif kualitatif, margin pemasaran, farmer share, efisiensi pemasaran. Hasil penelitian menunjukkan terdapat tiga level saluran pasar yang terbentuk dalam pemasaran buncis di Desa Oerinbesi yakni saluran I Petani $\rightarrow$ Konsumen, saluran II Petani $\rightarrow$ Pengecer $\rightarrow$ Konsumen (Konsumen Atambua dan Kefamenanu) serta saluran III Petani $\rightarrow$ Pengumpul $\rightarrow$ Pengecer $\rightarrow$ Konsumen (Konsumen Kefamenanu, Atambua dan Kupang). Margin pemasaran terbesar berada pada saluran pemasaran III khusus lokasi konsumen Kupang senilai Rp8.875,00 sedangkan terendah pada saluran I senilai Rp0,00 rata-rata nilai margin untuk tiga saluran pemasaran sebesar Rp3.402,50. farmer share tertinggi berada pada saluran I yakni $100 \%$ dan terendah pada saluran III lokasi Kupang yakni 31,06\%, rata-rata farmer share untuk tiga saluran pemasaran yakni Rp65.657,00. Pemasaran buncis di desa Oerinbesi berdasarkan pendekatan struktur, perilaku dan tampilan pasar menunjukkan hasil tidak efisien pada struktur dan perilaku pasar, sedangkan keragaman pasar menunjukkan hasil tidak efisien. (22017 dipublikasikan oleh Agrimor.

\section{Pendahuluan}

Buncis (Phaseolus vulgaris L.) merupakan sayuran yang berpotens ekonomi tinggi karena mempunyai peluang pasar yang cukup luas, baik di dalam maupun di luar negeri. Buncis merupakan salah satu sumber protein nabati yang murah dan mudah dikembangkan, serta mengandung vitamin, mineral, dan serat yang sangat berguna bagi perkembangan tubuh manusia (Rismunandar, 1982) Selanjutnya menurut Rukmana, (1998), permintaan pasar dalam negeri terhadap buncis biasanya meningkat cukup tajam pada hari raya, bahkan akhir-akhir in permintaan pasar swalayan di kota-kota besar tidak hanya berupa polong muda ukuran maksimal, tetapi juga polong muda berukuran kecil atau disebut "baby buncis".

Terdapat beberapa daerah di kabupaten Timor Tengah Utara (TTU) yang merupakan daerah penghasil buncis antara lain desa Oerinbesi di kecamatan Biboki Tanpah. Produksi buncis di wilayah kabupaten TTU pada tahun 2014 2016 berfluktuasi. Pada tahun 2014 total produksi buncis di kabupaten TTU 48 ton dan kecamatan Biboki Tanpah belum menghasilkan buncis (BPS Kab. TTU, 2015), selanjutnya tahun 2015 total produksi buncis di kabupaten TTU menurun menjadi 15,9 ton dengan kecamatan Biboki Tanpah menghasilkan 6,7 ton (BPS Kab. TTU, 2016), sedangkan tahun 2016 total produksi buncis di kabupaten TTU meningkat menjadi 98,9 ton dengan kecamatan Biboki Tanpah menghasilkan 21,1 ton (BPS Kab. TTU, 2017). Survei awal menunjukkan bahwa dengan luas lahan 10 are seorang petani di Oerinbesi dapat memproduksi $600 \mathrm{~kg}$ sampai 700 $\mathrm{kg}$ buncis per tahun.

Buncis yang dihasilkan di desa Oerinbesi kemudian dipasarkan baik untuk konsumen setempat maupun dipasarkan melalui pedagang perantara untuk konsumen pada lokasi lain. Konsumen buncis selain Desa Oerinbesi ada pula konsumen Kefamenanu, Atambua dan Kupang. Harga jual buncis bervariasi tergantung dari hasil produksi, biasanya berkisar dari Rp4.000,00 sampai Rp10.000,00 per kilogram.

Penelitian dan publikasi tentang pemasaran komoditi pertanian, dan perikanan di wilayah kabupaten TTU masih sangat minim, baru beberapa penelitian dan publikasi yang ada seperti margin pemasaran ikan di kecamatan Insana Utara (Selan \& Nubatonis, 2016), pemasaran pinang kering di kecamatan Kota Kefamenanu (Naimena \& Nubatonis, 2017), pemasaran sirih buah di desa Sunsea (Sasi \& Nubatonis, 2017), pemasaran usahatani padi sawah di desa Tualene (De Araujo \& Nubatonis, 2016), serta permintaan kacang tanah di kecamatan kota Kefamenanu (Salem \& Nubatonis, 2016). Hal ini menyebabkan berbagai pihak terkait sulit untuk mendapatkan informasi yang bisa digunakan sebagai pijakan pengambilan keputusan oleh pemerintah, produsen, pedagang maupun konsumen yang lebih berpihak kepada petani produsen. Oleh karena itu perlu dilakukan penelitian dengan topik "Analisis Pemasaran Buncis di Desa Oerinbesi Kecamatan Biboki Tanpah Kabupaten Timor Tengah Utara". Penelitian ini bertujuan untuk mengetahui 1) saluran pemasaran; 2) margin pemasaran; 3) farmer share; dan 4) efisiensi pemasaran buncis di desa Oerinbesi, kecamatan Biboki Tanpah, kabupaten TTU.

\section{Metode}

Penelitian ini dilaksanakan di desa Oerinbesi, kecamatan Biboki Tanpah, kabupaten TTU pada bulan Februari sampai Juli 2017. Metode yang digunakan dalam pengambilan sampel adalah metode sensus, ini dikarenakan jumlah populasi bersifat jenuh sehingga populasi tersebut dijadikan sampel yakn sebanyak 35 petani buncis. Penentuan sampel untuk pedagang perantara digunakan metode snowball, metode ini digunakan dengan cara menggali informasi dari penjual sebelumnya untuk mendapat informasi kepada siapa produknya dijual.

Metode analisis yang digunakan adalah deskriptif kualitatif untuk menjawab tujuan pertama yakni mengetahui saluran pemasaran, untuk mengetahui selisih harga antara produsen dan konsumen dihitung dengan rumus $\mathrm{M}=\mathrm{Pr}-\mathrm{Pf}$ dimana M: margin pemasaran; Pr: harga ditingkat konsumen; dan Pf: harga ditingkat produsen. Besarnya bagian yang diterima petani dihitung dengan rumus $\mathrm{F}=(\mathrm{Pf}$ / Pr) x 100\% dimana F: bagian yang diterima petani; Pf: harga buncis di tingkat petani; dan Pr: harga buncis di tingkat konsumen. Efisiensi pemasaran diukur dengan menggunakan pendekatan struktur, perilaku dan keragaman pasar. Struktur pasar ditentukan dengan CR4 $=\left(\mathrm{MS}_{1}+\ldots+\mathrm{MS}_{4}\right) / \mathrm{MS}_{\text {Total }}$, dimana CR4 concentration ratio for the bigest four dan $\mathrm{MS}_{\text {Total }}$ : total market share. Perilaku pasar ditentukan dengan mendeskripsikan cara promosi produk dan teknik penentuan harga, sedangkan keragaman pasar diukur dengan margin pemasaran dan farmer share dimana biaya harus lebih kecil dari keuntungan margin dan nilai F > 50\% (Sudiyono, 2002).

\section{Hasil dan Pembahasan}

Petani produsen buncis dalam satu tahun hanya melakukan satu kali penanaman dan mampu memproduksi atau panen sampai 12 kali. Hasil buncis dari petani di Desa Oerinbesi kemudian dipasarkan melalui berbagai lembaga pemasaran. Pilihan petani dalam memasarkan buncis tidak tetap terkadang dijual kepada pengecer terkadang dijual kepada pemborong. Pilihan-pilihan tersebut kemudian membentuk saluran pemasaran.

\subsection{Saluran Pemasaran}

Saluran pemasaran merupakan sebuah struktur bisnis yang terdiri atas organisasi-organisasi yang saling berkaitan, dimulai dari tempat asal mula produk dibuat sampai konsumen terakhir dengan maksud memindahkan produk serta kepemilikan ke pemakai terakhir, yaitu konsumen pribadi atau pengguna bisnis. Proses pemasaran buncis yang terjadi di desa Oerinbesi dapat dilihat pada Gambar 1

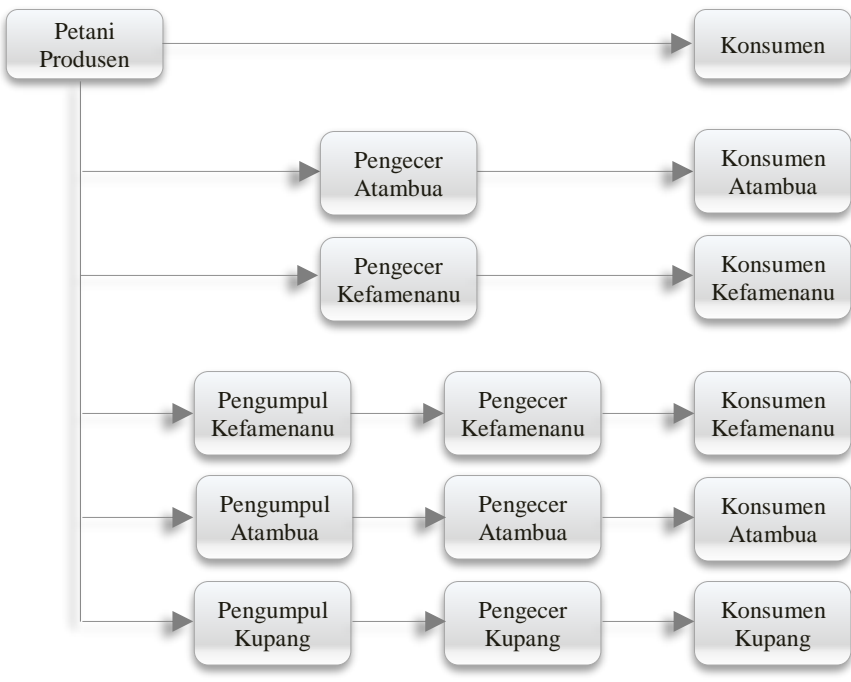

Gambar 1. Saluran Pemasaran Buncis di Desa Oerinbesi

Gambar 1. menunjukkan terbentuknya beberapa saluran pemasaran di Desa Oerinbesi tetapi secara umum hanya ada tiga level pasar yang terbentuk kemudian terbagi lagi dalam lokasi konsumen. Berikut ini merupakan uraian lebih rinci mengenai saluran-saluran pemasaran yang terbentuk berdasarkan alur pemasaran buncis dan lokasi pemasaran buncis dari desa Oerinbesi. 
a. Saluran I Petani $\rightarrow$ Konsumen

Saluran pertama yang terbentuk adalah saluran dimana petani langsung menjual kepada konsumen di desa Oerinbesi baik di lahan ataupun pasar terdekat yakni pasar Oenopu.

\section{b. Saluran II Petani $\rightarrow$ Pengecer $\rightarrow$ Konsumen}

Saluran kedua yang terbentuk adalah saluran dimana produk mengalami perpindahan melalui beberapa lembaga dan mengalami beberapa penambahan nilai guna yang berakibat pada harga yang semakin meningkat. Berikut merupakan perincian penyaluran produk buncis di Kefamenanu dan Atambua.

- Petani $\rightarrow$ Pengecer Atambua $\rightarrow$ Konsumen Atambua

Saluran pemasaran yang dilalui produk buncis untuk sampai pada konsumen Atambua salah satunya melalui pedagang pengecer. Petani yang memilih memasarkan buncisnya langsung kepada pengecer Atambua sebanyak lima responden dari delapan responden $(62,5 \%)$.

- Petani $\rightarrow$ Pengecer Kefamenanu $\rightarrow$ Konsumen Kefamenanu

Saluran pemasaran yang dilalui produk buncis untuk sampai kepada konsumen Kefamenanu salah satunya melalui lembaga pemasaran yakni pedagang pengecer. Petani yang memilih memasarkan buncisnya melalui pengecer Kefamenanu sejumlah tiga responden dari 8 responden petani $(37,5 \%)$.

\section{c. Saluran III Petani $\rightarrow$ Pengumpul $\rightarrow$ Pengecer $\rightarrow$ Konsumen}

Saluran ketiga adalah saluran buncis yang dimulai dari petani produsen desa Oerinbesi ke pedagang pengumpul kemudian ke pedagang pengecer dan berakhir pada konsumen. Saluran ini menunjukkan banyaknya lembaga pemasaran yang dilewati oleh produk (buncis) dibandingkan dua saluran lainnya. Perpindahan produk dari satu lembaga ke lembaga lain seterusnya sampai pada konsumen akhir menjadikan harga buncis pada tingkatan terakhir lebih tinggi dari pada tingkatan sebelumnya. Berikut merupakan perincian saluran pemasaran buncis berdasarkan lokasi konsumen melalui saluran ketiga.

○ Petani $\rightarrow$ Pedagang Pengumpul desa $\rightarrow$ Pedagang Pengecer Atambua $\rightarrow$ Konsumen Atambua

Saluran pemasaran dua menunjukkan bagaimana buncis tersalurkan melalui pengecer Atambua sedangkan pada saluran ke tiga, buncis awalnya dikumpulkan oleh pengumpul desa dan disalurkan ke pengecer Atambua dan berakhir ke konsumen. Empat orang responden $(44,45 \%)$ menyatakan pemasarannya dilakukan ke pengumpul desa.

○ Petani $\rightarrow$ Pedagang Pengumpul desa $\rightarrow$ Pedagang Pengecer Kefamenanu $\rightarrow$ Konsumen Kefamenanu

Pada saluran ini, empat dari sembilan responden $(44,45 \%)$ yang menyalurkan buncisnya melalui pengumpul desa dan menyalurkan ke pengecer Kefamenanu.

○ Petani $\rightarrow$ Pedagang Pengumpul Kupang $\rightarrow$ Pengecer Kupang $\rightarrow$ Konsumen Kupang

Pedagang pengumpul Kupang merupakan pedagang Kupang yang mengumpulkan hasil dari desa Oerinbesi berupa buncis untuk disalurkan ke pengecer Kupang sampai pada Konsumen. Dari sembilan responden ternyata satu responden $(11,1 \%)$ yang menyalurkan buncisnya ke Kupang.

\subsection{Margin Pemasaran Buncis}

Pemasaran buncis yang terjadi di desa Oerinbesi dilakukan oleh beberapa lembaga pemasaran, maka margin pemasaran bukan hanya merupakan selisih antara harga beli konsumen dan harga jual produsen tetapi merupakan jumlah margin-margin dari setiap lembaga pemasaran yang bersangkutan. Margin pemasaran pada dasarnya terdiri atas dua komponen penting yakni biaya-biaya operasional (biaya pemasaran) dan keuntungan (profit). Saluran pemasaran yang telah diketahui menunjukkan perbedaan margin dari setiap lembaga pada saluran pemasaran tersebut.

Tabel 1. Margin Pemasaran Buncis di desa Oerinbesi

\begin{tabular}{lrrrrr}
\hline \multicolumn{1}{c}{ Saluran } & $\begin{array}{c}\text { Harga } \\
\text { Jual (Rp) }\end{array}$ & $\begin{array}{c}\text { Harga } \\
\text { Beli (Rp) }\end{array}$ & $\begin{array}{c}\text { Total Biaya Keuntungan } \\
(\mathrm{Rp})\end{array}$ & $\begin{array}{c}\text { Margin } \\
\text { Pemasaran } \\
(\mathrm{Rp})\end{array}$ & $\begin{array}{c}\text { Pem } \\
\text { (Rp) }\end{array}$ \\
\hline I & & & & & \\
II. Kefamenanu & 8250 & 7000 & 1052 & 198 & 1250 \\
II. Atambua & 8475 & 7000 & 870 & 605 & 1475 \\
III. Kefamenanu & 8194 & 4000 & 900 & 3294 & 4194 \\
III. Atambua & 8621 & 4000 & 948,57 & 3673 & 4621 \\
III. Kupang & 12875 & 4000 & 2768 & 6107 & 8875 \\
\hline
\end{tabular}

Tabel 1. menunjukkan margin pemasaran setiap saluran pemasaran. Saluran pertama tidak dapat dihitung sebab dalam penelitian ini tidak memperhitungkan biaya untuk memproduksi buncis. Total biaya dalam Tabel 1. merupakan akumulasi dari biaya pemasaran antara lain biaya transportasi, biaya pengepakan, retribusi, dan biaya lain-lain. Margin pemasaran saluran II lokasi konsumen Kefamenanu sebesar Rp1.250,00 sedangkan lokasi Atambua Rp1.475,00 saluran II lokasi konsumen Kefamenanu Rp4.194,00, Atambua Rp4.621,00 dan Kupang Rp8.875,00.

\subsection{Bagian Harga yang Diterima Petani (Farmer Share)}

Bagian harga yang diterima petani merupakan persentase yang didapat oleh petani hari usahataninya, hal ini dapat dilihat pada Tabel 2. Nilai farmer share tertinggi berbeda pada saluran I sebesar $100 \%$ ini dikarenakan petani langsung menyalurkan buncisnya ke konsumen setempat sehingga biaya yang dikeluarkan minim.

\begin{tabular}{lccc} 
Tabel 2. Farmer Share & & \\
\hline \multicolumn{1}{c}{ Saluran } & Harga Beli & Harga Jual & $\begin{array}{c}\text { Farmer Share } \\
(\%)\end{array}$ \\
\hline I & 4000 & 4000 & 100 \\
II. Kefamenanu & 7000 & 8250 & 84,89 \\
II. Atambua & 7000 & 8475 & 82,59 \\
III. Kefamenanu & 4000 & 8194 & 48,81 \\
III. Atambua & 4000 & 8621 & 47,19 \\
III. Kupang & 4000 & 12875 & 31,06 \\
\hline
\end{tabular}

\subsection{Efisiensi Pemasaran}

Pada dasarnya menentukan suatu pemasaran efisien ataupun tidak efisien sangat sulit karena dalam proses pemasaran pada umumnya melibatkan empat komponen besar yakni produsen, lembaga perantara, konsumen dan pemerintah. Dalam pemasaran hasil pertanian tidak hanya keempat komponen tersebut saja tetapi karakteristik dasar dari hasil-hasil pertanian juga terlibat di dalamnya (Sudiyono, 2002)

Pemasaran buncis di desa Oerinbesi, diukur dengan pendekatan struktur, perilaku dan keragaman pasar yang menghasilkan asumsi peneliti bahwa pemasaran buncis di desa Oerinbesi tergolong tidak efisien karena dua dari tiga pendekatan menunjukkan hasil yang tidak efisien.

a. Struktur Pasar

Sangat penting menentukan struktur pasar dalam pemasaran pertanian, ini dikarenakan sifat hasil pertanian yang masal dan homogen. Karena itu struktur pasar dalam pemasaran buncis desa Oerinbesi ini dapat dilihat pada Tabel 3.

\section{Tabel 3. CR4}

\begin{tabular}{lccccc}
\hline No & $\begin{array}{c}\text { Jumlah penjualan } \\
\text { Buncis (kg) }\end{array}$ & $\begin{array}{c}\text { Market } \\
\text { Share }\end{array}$ & $(\%)$ & CR4 & SP \\
\hline 1. Pemborong (Pengumpul) & & & & \\
\hline 1 & 500 & 0,15152 & 15,15 & & \\
2 & 500 & 0,15152 & 15,15 & 0,54 & \\
3 & 400 & 0,12121 & 12,12 & & \\
4 & 400 & 0,12121 & 12,12 & & \\
\hline Jumlah & & & 54,54 & 54 & \\
\hline 2. Pengecer & & & & \\
\hline 1 & 70 & 0,12727 & 12,72 & & \\
2 & 70 & 0,12727 & 12,72 & 0,4906 & \\
3 & 65 & 0,11818 & 11,81 & \\
4 & 65 & 0,11818 & 11,81 & & \\
\hline Jumlah & & & 49,06 & 49,06 & \\
\hline
\end{tabular}

Keterangan: $\mathrm{O}=$ Oligopoli

Dari Tabel 3. dapat dilihat bahwa struktur pasar yang terbentuk yakni oligopoli. Suatu struktur pasar dikatakan efisien apabila termasuk dalam struktur pasar persaingan sempurna karena struktur pasar buncis di desa Oerinbesi termasuk dalam struktur pasar persaingan tidak sempurna maka struktur pasar buncis di desa Oerinbesi tidak efisien. Selain secara kuantitas yang dihitung berdasarkan CR4, adapun kriteria secara kualitatif yang menunjukkan tidak efisien struktur pasar yang terbentuk dimana lembaga pemasaran yang ada tidak memadai dalam proses pemasaran, produk hasil dihasilkan homogen dan tidak ada diferensiasi produk buncis dan dalam hal kebebasan masuk keluar pasar tidak ada halangan bagi pedagang lama tapi akan sangat sulit bagi pedagang baru karena kebanyakan petani memasarkan buncis kepada pedagang yang sudah lama bekerjasama. Hal ini menunjukkan struktur pasar dalam pemasaran buncis di desa Oerinbesi tidak efisien.

\section{b. Perilaku Pasar}

Petani tidak melakukan promosi melalui koran, majalah, radio atau media lain. Promosi dilakukan dengan cara memamerkan keunggulan buncisnya apabila ada pedagang pengumpul yang masuk ke desa tersebut. Penetapan harga dilakukan dengan proses tawar menawar antara pembeli dan petani tetapi kebanyakan petani hanya sebagai price taker dan tidak adanya standar harga dari pemerintah yang membantu petani dalam penentuan harga, sedangkan dalam hal perlindungan terhadap praktik pemasaran yang tidak efisien dalam penelitian ini tidak ditemukan sehingga banyak sekali taktik pembeli yang merugikan petani produsen. Hal ini menunjukkan perilaku pasar yang tidak efisien.

\section{c. Keragaman Pasar}

Keragaman pasar secara kuantitatif diukur berdasarkan nilai margin pemasaran dan farmer share dengan kriteria keragaman pasar yang efisien apabila biaya < keuntungan dan farmer share > 50\%. Perhitungan biaya pemasaran dapat dilihat melalui margin dan farmer share pada Tabel 4.

Hasil perhitungan margin pemasaran maupun farmer share pada Tabel 4. menunjukkan hasil untuk keragaman pasar efisien dimana rata-rata keuntungan lebih besar dari rata-rata biaya $(\mathrm{Rp} 2.227,00>\mathrm{Rp} 1.174,00)$ dan rata-rata farmer share $>50 \%(66 \%)$ 
Tabel 4. Rata-rata margin dan farmer share

\begin{tabular}{|c|c|c|c|c|}
\hline \multirow{2}{*}{$\begin{array}{c}\text { Saluran } \\
\text { Pemasaran }\end{array}$} & \multicolumn{3}{|c|}{ Margin Pemasaran } & \multirow{2}{*}{$\begin{array}{c}\text { Farmer } \\
\text { Share }\end{array}$} \\
\hline & Total Biaya & Keuntungan & Margin & \\
\hline \multicolumn{5}{|l|}{ I } \\
\hline II. Kefamenanu & 1052 & 198 & 1250 & 84,89 \\
\hline II. Atambua & 870 & 605 & 1475 & 82,59 \\
\hline Total II & 1922 & 803 & 2725 & \\
\hline III. Kefamenanu & 900 & 3294 & 4194 & 48,81 \\
\hline III. Atambua & 948,57 & 3673 & 4621 & 47,19 \\
\hline III. Kupang & 2768 & 6107 & 8875 & 31,06 \\
\hline Total III & 4613,57 & 13074 & 17690 & \\
\hline Total Margin & 7049,85 & 13363 & 20415 & 394,54 \\
\hline Rata-rata & 1174,975 & 2227,167 & 3402,5 & 65,757 \\
\hline
\end{tabular}

\section{Simpulan}

Terdapat tiga level saluran pasar yang terbentuk dalam pemasaran buncis di Desa Oerinbesi yakni saluran I Petani $\rightarrow$ Konsumen, saluran II Petani $\rightarrow$ Pengecer $\rightarrow$ Konsumen (Konsumen Atambua dan Kefamenanu) serta saluran III Petani $\rightarrow$ Pengumpul $\rightarrow$ Pengecer $\rightarrow$ Konsumen (Konsumen Kefamenanu, Atambua dan Kupang). Margin pemasaran terbesar berada pada saluran pemasaran III khusus lokasi konsumen Kupang senilai Rp8.875,00 sedangkan terendah pada saluran I senilai Rp0,00 rata-rata nilai margin untuk tiga saluran pemasaran sebesar Rp3.402,50. farmer share tertinggi berada pada saluran I yakni $100 \%$ dan terendah pada saluran III lokasi Kupang yakni 31,06\%, rata-rata farmer share untuk tiga saluran pemasaran yakni Rp65.657,00. Pemasaran buncis di desa Oerinbesi berdasarkan pendekatan struktur, perilaku dan tampilan pasar menunjukkan hasil tidak efisien pada struktur dan perilaku pasar, sedangkan keragaman pasar menunjukkan hasil tidak efisien.

\section{Pustaka}

BPS Kab. TTU 2015. Timor Tengah Utara dalam Angka 2015. Kefamenanu: Badan Pusat Statistik Kabupaten TTU.

BPS Kab. TTU 2016. Kabupaten Timor Tengah Utara dalam Angka 2016. Kefamenanu: Badan Pusat Statistik Kabupaten TTU.

BPS Kab. TTU 2017. Kabupaten Timor Tengah Utara dalam Angka 2017. Kefamenanu: Badan Pusat Statistik Kabupaten TTU.

De Araujo, M. \& Nubatonis, A. 2016. Analisis Produksi dan Pemasaran Usahatani Padi Sawah di Desa Tualene Kecamatan Biboki Utara Kabupaten Timor Tengah Utara. AGRIMOR, 1(03): 55-56.

Naimena, F. \& Nubatonis, A. 2017. Analisis Pemasaran Pinang Kering Oleh Pedagang di Kecamatan Kota Kefamenanu Kabupaten Timor Tengah Utara. AGRIMOR, 2(02): 27-29.

Rismunandar 1982. Bertanam Sayur-sayuran. Bandung: Terate.

Rukmana, R. 1998. Bertanam Buncis. Yogyakarta: Kanisius.

Salem, F. \& Nubatonis, A. 2016. Faktor-Faktor yang Mempengaruhi Permintaan Kacang Tanah di Kecamatan Kota Kabupaten Timor Tengah Utara. AGRIMOR, 1(01): 7-9.

Sasi, W. \& Nubatonis, A. 2017. Pemasaran Sirih Buah di Desa Sunsea, Kecamatan Naibenu, Kabupaten Timur Tengah Utara. AGRIMOR, 2(01): 1 3.

Selan, D.M. \& Nubatonis, A. 2016. Margin Pemasaran Ikan di Kecamatan Insana Utara Kabupaten Timor Tengah Utara. AGRIMOR, 1(03): 63-64.

Sudiyono, A. 2002. Pemasaran Pertanian. 2 ed. 2. Malang: UMM Press. 